\title{
EARLY BROOD-REARING HABITAT USE AND PRODUCTIVITY OF GREATER SAGE-GROUSE IN WYOMING
}

\author{
Kristin M. Thompson ${ }^{1,3,5}$, Matthew J. Holloran ${ }^{1,3}$, Steven J. Slater ${ }^{1,4}$, \\ Jarren L. Kuipers ${ }^{1,2}$, and Stanley H. Anderson ${ }^{1}$
}

\begin{abstract}
Populations of Greater Sage-Grouse (Centrocercus urophasianus) have been declining throughout their range since the 1960s. Productivity, which includes production and survival of young, is often cited as a factor in these declines. We monitored radio-equipped Greater Sage-Grouse at 3 sites in western Wyoming to assess early brood-rearing habitat use (through 14 days post-hatch) and productivity. Logistic and linear regression analyses with Akaike's Information Criterion were used to evaluate early brooding habitat use and to examine relationships between productivity and vegetation, insect size and abundance, and weather parameters. Females with broods were found in areas with greater sagebrush canopy and grass cover, and fewer invertebrates compared to random areas. The number of juveniles per female (estimated from wing barrel collections during fall harvest) was positively related to the abundance of medium-length Hymenoptera and grass cover, and the proportion of females with confirmed chicks 14 days post-hatch was positively related to abundance of medium-length Coleoptera and total herbaceous cover. Although the specific parameters varied slightly, Greater Sage-Grouse productivity in Wyoming appeared to be associated with a combination of insect and herbaceous cover elements. Managing for abundant and diverse insect communities within dense protective sagebrush stands should help ensure high-quality early brood-rearing habitat and increased Greater Sage-Grouse productivity.
\end{abstract}

Key words: Greater Sage-Grouse, early brood rearing, Centrocercus urophasianus, habitat, productivity, sagebrush, invertebrate, forb.

Over the past 50 years, populations of Greater Sage-Grouse (Centrocercus urophasianus) have experienced widespread declines (Patterson 1952, Braun 1998, Connelly et al. 2004). Extirpated from 3 states and 1 Canadian province by 1998, the bird is now the focus of conservation and management concern in most of its remaining range (Connelly et al. 2004). Wyoming remains a stronghold for Greater Sage-Grouse, where breeding bird numbers were estimated at $>20,000$ in 1998 (Braun 1998). However, populations throughout Wyoming have also suffered declines; breeding male numbers decreased by an average of $5.2 \%$ annually between 1965 and 2003 (Connelly et al. 2004).

Population declines in tetraonids are often attributed to changes in productivity (Blank et al. 1967, Bergerud 1988). Productivity (i.e., the production and survival of young) may be affected by a variety of mainly extrinsic factors, including food availability and weather.
Because sage grouse chicks require a highprotein diet (Johnson and Boyce 1990), invertebrates are essential diet components for several weeks post-hatch. Insects dominated the diets of 1-week-old Greater Sage-Grouse chicks in Idaho (Klebenow and Gray 1968), Montana (Peterson 1970), and Colorado (Huwer 2004). Greater Sage-Grouse broods were documented using areas with high arthropod abundance in Idaho (Fischer et al. 1996). Researchers using captive Greater Sage-Grouse chicks in Wyoming found that all chicks not given insects during the first 10 days post-hatch died, whereas all chicks given insects during this time survived (Johnson and Boyce 1990).

After the first 1 or 2 weeks, forbs began to gain importance in the diet of chicks. Forbs comprised $75 \%$ of the diet of juvenile Greater Sage-Grouse in Montana (Peterson 1970) and were found in $100 \%$ of the crops of 2 -week-old Greater Sage-Grouse chicks sampled in Idaho (Klebenow and Gray 1968). Productivity of

\footnotetext{
${ }^{1}$ Wyoming Cooperative Fish and Wildlife Research Unit, University of Wyoming, Laramie, WY 82071.

2Present address: Nebraska Game and Parks Commission, Beatrice, NE 68310.

${ }^{3}$ Present address: Wyoming Wildlife Consultants, LLC, Laramie, WY 82072

4 Present address: HawkWatch International, Inc., Salt Lake City, UT 84115.

${ }^{5}$ Corresponding author. E-mail: kmthomps@uwyo.edu
} 
Greater Sage-Grouse in Oregon was higher in areas where chicks consumed a greater proportion of forbs and insects (Drut et al. 1994a), and the mass gain of human-imprinted chicks in Colorado was positively correlated with forb abundance in the diet (Huwer 2004). Forbs may also provide a food source for chicks by attracting invertebrates (Blenden et al. 1986, Hull et al. 1996, Jamison et al. 2002). Forb cover, including species found in the diet, was higher at sites used by Greater Sage-Grouse broods compared to nonbrooding sites in Colorado (Schoenberg 1982), Idaho (Klebenow 1969), Oregon (Drut et al. 1994b), Washington (Sveum et al. 1998), and Wyoming (Holloran 1999).

Weather may also influence productivity during the nesting and brood-rearing periods (April-August). Cold temperatures may delay nest initiation (Neave and Wright 1969) or stress incubating females (Smyth and Boag 1984). Spruce Grouse (Dendragapus canadensis) incubating in cold and wet environments produced fewer chicks per hen (Smyth and Boag 1984). Similarly, productivity of Sharptailed Grouse (Tympanuchus phasianellus) was positively correlated with average May temperatures (Flanders-Wanner et al. 2004). Newly hatched chicks have poorly developed thermoregulatory systems (Myhre et al. 1975, Aulie 1976), so they are vulnerable to extreme weather conditions during the early post-hatch period. A combination of low temperatures, continuous winds, and precipitation negatively influenced Greater Sage-Grouse brood size during the early hatching period in Idaho (Dalke et al. 1963). The number of juveniles per harvested adult Sharp-tailed Grouse was positively associated with average June temperatures but negatively correlated with June precipitation (Flanders-Wanner et al. 2004); and fall harvest numbers of Ruffed Grouse were positively linked to warmer temperatures in June (Ritcey and Edwards 1963).

Several studies have shown a relationship between brood habitat use and the availability of invertebrates (Erikstad 1985, Storch 1994, Fischer et al. 1996, Haulton et al. 2003) and forbs (Klebenow 1969, Peterson 1970, Wallestad 1971, Drut et al. 1994b, Sveum et al. 1998, Holloran 1999). Other vegetation variables, including sagebrush or shrub canopy cover (Klebenow 1969, Wallestad 1971, Schoenberg 1982, Klott and Lindzey 1990, Holloran 1999), shrub height (Martin 1970, Dunn and
Braun 1986, Sveum et al. 1998, Holloran 1999), and grass or residual grass cover (Sveum et al. 1998, Holloran 1999), may also influence brood habitat use. Literature exists on the importance of vegetation, invertebrates, and weather to various grouse species. However, research on how these factors influence Greater SageGrouse early brood-rearing habitat use is lacking, and some of the factors potentially influencing productivity remain largely speculative. Additionally, most work has focused on the independent importance of these variables; little work has examined their relative importance or their interactions. Our objectives were to determine the specific habitat components associated with early brood-rearing habitat use of Greater Sage-Grouse and to establish the factors most strongly related to Greater Sage-Grouse productivity.

\section{Study AREA}

We conducted this research at 3 sites in western Wyoming. The 30,400-ha Pinedale study area $\left(42^{\circ} 45^{\prime} \mathrm{N}, 109^{\circ} 55^{\prime} \mathrm{W}\right)$ was located at elevations ranging between $2140 \mathrm{~m}$ and 2300 $\mathrm{m}$ and, during the nesting and brood-rearing period (April-August), had a mean temperature of $10.1^{\circ} \mathrm{C}$ and mean precipitation of $14.7 \mathrm{~cm}$. The 45,900 -ha Lander site $\left(42^{\circ} 33^{\prime} \mathrm{N}, 108^{\circ} 29^{\prime} \mathrm{W}\right)$ was located at elevations ranging between $1730 \mathrm{~m}$ and $2470 \mathrm{~m}$. Temperatures during the nesting and brood-rearing period averaged $15.7^{\circ} \mathrm{C}$, and mean precipitation between April and August was $17.8 \mathrm{~cm}$. The 55,000-ha Kemmerer site $\left(45^{\circ} 53^{\prime} \mathrm{N}, 110^{\circ} 54^{\prime} \mathrm{W}\right)$ was located at elevations ranging between $1900 \mathrm{~m}$ and 2510 m. Between April and August, mean temperature was $11.4^{\circ} \mathrm{C}$, and precipitation averaged 14 cm (Western Regional Climate Center, Reno, Nevada). For detailed descriptions of the study areas see Lyon (2000), Slater (2003), and Kuipers (2004).

All 3 sites were dominated by sagebrush (Artemisia spp.), mainly Wyoming big sagebrush (A. tridentata wyomingensis). Other common shrub species included basin big sagebrush (A. tridentata tridentata), mountain big sagebrush (A. tridentata vaseyana), saltbush (Atriplex spp.), rabbitbrush (Chrysothamnus spp.), and bitterbrush (Purshia spp.). Wheatgrasses (Agropyron spp.) and bromes (Bromus spp.) dominated the grass family representatives, while western yarrow (Achillea millefolium), 
dandelion (Taraxacum officinale), and lupine (Lupinus spp.) were among the most common forbs.

\section{Methods}

We collected data at the Pinedale site between 1999 and 2003, at the Lander site between 2000 and 2003, and at the Kemmerer site between 2000 and 2002, for a total of 12 site-years. Female Greater Sage-Grouse were captured at leks in the early spring of each year using spotlighting and hoop-netting techniques (Giesen et al. 1982, Wakkinen 1992). Females were fitted with 19.5 - or 25.5 -g wirenecklace radio-transmitters (Advanced Telemetry Systems, Inc., Isanti, MN) and tracked with handheld radio-telemetry receivers and 3-element Yagi antennas. Females were located within the first 2 weeks of incubation to determine nesting locations, and nest fate (successful or unsuccessful) was determined when the female left the nesting area. A nest was considered successful if $\geq 1$ egg hatched, determined by presence of detached eggshell membranes (Girard 1939). Early brood-use locations were obtained between 6 and 14 days post-hatch for females whose nests successfully hatched. For comparison with early brood locations (i.e., use habitat plots), random habitat locations were obtained by random generation of easting and northing locations within the study areas.

Vegetation and insect characteristics were measured at both use plots and random plots. Sagebrush canopy cover $(\%)$ was estimated at each plot using the line-intercept method (Canfield 1941) in which 2 perpendicular 30-m transects were centered on each plot. A 1-mwide belt transect was created over the $30-\mathrm{m}$ transects to estimate live sagebrush density (plants $\cdot \mathrm{m}^{-2}$; counted plants included those for which $\geq 50 \%$ of the plant was within the belt transect). Live sagebrush height $(\mathrm{cm})$ was estimated as the maximum height, excluding flowering stalks, of each sagebrush plant encountered during line-intercept sampling. Ground cover (\%) of herbaceous species (new [i.e., current year's growth] grasses, residual [i.e., standing dead] grasses, and forbs) was estimated using the Daubenmire (1959) method: a $20 \times 50$-cm open-ended frame was placed over sampling plots located at 0,1 , and $2.5 \mathrm{~m}$ from the center of each transect (12 total frames per plot). We converted categorical estimates of herbaceous cover to percentages (category $1=2.5 \%, 2=15 \%, 3=37.5 \%, 4=62.5 \%, 5=$ $85 \%, 6=97.5 \%$; Daubenmire 1959) for each of the 12 frames per plot. Converted cover estimates from the 12 frames were averaged to derive a single estimate for each variable per plot. Herbaceous vegetation variables included total herbaceous cover (all new and residual grasses and forbs), forb cover (including winterfat [Eurotia lanata] and fringed sagewort [Artemisia frigida]), new grass cover, and residual grass cover. Ground cover estimates were also calculated for litter and bare ground. The height $(\mathrm{cm})$ of new and residual grasses was determined by measuring the tallest grasses that occurred relatively frequently within each Daubenmire frame (heights were meant to be representative of the herbaceous community; single, very tall blades were not included). Height estimates from the 12 Daubenmire frames were averaged to derive single grass height estimates per plot.

Arthropods were sampled using pitfall traps (Greenslade 1964) established along the vegetation transects at distances of $0,1,2.5,7$, and $15 \mathrm{~m}$ from the center (17 total pitfall traps per plot). Traps were left open for 48 hours. Isopropanol was used to kill and preserve trapped insects. Trap contents were sorted to order, except for arachnids, which were sorted to class. Arthropods were further sorted into 3 length categories according to guidelines developed from Patterson (1952) and Whitmore et al. (1986). Arthropods $<3 \mathrm{~cm}$ were considered small; those $3-11 \mathrm{~cm}$ were considered medium; and those $>11 \mathrm{~cm}$ were classified as large. Soft-bodied larvae, such as grubs and caterpillars, were an exception; the medium length class contained arthropods between 3 $\mathrm{cm}$ and $15 \mathrm{~cm}$, and only those $>15 \mathrm{~cm}$ were considered large. The medium length class of invertebrates was considered most likely to be selected and eaten by foraging chicks. Per plot abundances were calculated for each order and length category of invertebrates.

\section{Statistical Analyses}

All site-years with 5 or fewer use plots were removed because the small sample size did not allow for accurate representation of the site; this removal left 8 site-years for use in further analyses. Data for these remaining site-years were winsorized (i.e., outliers in an 
ordered array were replaced by their neighboring values; Sokal and Rohlf 1995), because single outlying data points (e.g., pitfall traps located on anthills) were unduly influencing site values in certain instances.

Habitat UsE.-Data were standardized by site (by subtracting the mean and dividing by the standard deviation; Sokal and Rohlf 1995) to minimize any influence of site on the results. We used logistic regression to examine habitatuse relationships (use sites versus random sites; $n=262$ ). From our original group of variables, we selected 11 variables to represent 3 vegetation and insect components. Variable selection was based on both correlation analyses and published literature (including Klebenow 1969, Dunn and Braun 1986, Klott and Lindzey 1990, Drut et al. 1994b, Fischer et al. 1996, Pyle and Crawford 1996, and Holloran 1999). Where strong correlations existed between variables (e.g., between sagebrush canopy cover, total shrub canopy cover, and litter cover), 1 variable from the group was selected based on its importance in the literature. The abundances of several insect variables, including Orthoptera, were too small to be used in analyses. Sagebrush canopy cover, live sagebrush density, and sagebrush height represented the shrub component; total forb cover, total grass (new + residual grass) cover, mean grass (new + residual grass) height, and total herbaceous cover represented the herbaceous component; and total invertebrate abundance, total Hymenoptera abundance, medium-length Hymenoptera abundance, and medium-length Coleoptera abundance represented the insect component. Because this research was primarily exploratory, all possible 2- and 3-variable combinations were used in logistic regression analyses. To reduce multicollinearity, we did not include variable combinations containing variables correlated by a Pearson's correlation coefficient $>0.70$. Our suite of candidate models included 62 models. Models were ranked using a small-sample, bias-adjusted Akaike's Information Criterion $\left(\mathrm{AIC}_{c}\right.$; Burnham and Anderson 2002). Akaike weights $\left(w_{i}\right)$ were used to assess the relative importance of each vegetation and insect variable in distinguishing between use sites and random sites (Burnham and Anderson 2002). Cumulative Akaike weights were estimated from the entire set of models.

Productivity.-Productivity was measured by 2 variables: juveniles per female and the proportion of females with confirmed chicks 14 days post-hatch. Juveniles-per-female values were obtained from the Wyoming Game and Fish Department and were calculated using juvenile-to-adult ratios in wing barrel collections in the fall harvest (Autenrieth et al. 1982, Connelly et al. 2000; data from Wyoming Game and Fish Department harvest reports, Cheyenne, WY). To ensure that estimates of juveniles per female were comparable to our habitat measurements, we only used harvest estimates from areas where radioequipped females were located during the hunting season. The proportion of females with confirmed chicks was defined as the percentage of successfully nesting females with $\geq 1$ chick alive 14 days post-hatch. The presence of chicks was based on visual confirmation and brooding females' reactions to researcher presence (Schroeder et al. 1999). To confirm brood loss, we relocated successfully nesting females recorded as having no chicks alive 2-5 days following the initial location. Vegetation, insect, and weather variables were again selected based on correlation analyses and their importance in the literature (including Dalke et al. 1963, Klebenow and Gray 1968, Peterson 1970, and Drut et al. 1994a). Vegetation parameters included total forb cover, total grass cover, mean grass height, and total herbaceous cover; the insect component was composed of total invertebrate abundance, total Hymenoptera abundance, medium-length Hymenoptera abundance, and medium-length Coleoptera abundance. We used 1-way analysis of variance (ANOVA) to examine the effect of site and year on the variables; those variables that differed significantly by site or year $(P \leq 0.1)$ were standardized by site (Sokal and Rohlf 1995).

Weather data were obtained from the Western Regional Climate Center (Reno, NV). Where data were unavailable, we extrapolated (using kriging techniques in a GIS; Burrough and McDonnell 1998) using data from nearby weather stations. To minimize effects of site, both temperature and precipitation variables were calculated as a percentage of average (period of record: 1948-2004). It seemed likely that the interaction of temperature and precipitation could have a greater effect on productivity than either variable alone, so we created a combination temperature-precipitation (TempPre) variable, calculated by dividing 
temperature by precipitation. Therefore, a hot and dry month would have a high TempPre value, whereas a cold and wet month would have a low TempPre value. The TempPre variable was developed for April-May (AprMay_ TempPre), June (Jun_TempPre), and JulyAugust (JulAug_TempPיe). Because estimates of the proportion of females with confirmed chicks were generated by mid-June, JulAug TempPre was included only in the analysis of juveniles per female.

We generated a suite of models using our selected vegetation, insect, and weather variables. To avoid overparameterizing the models (Hosmer and Lemeshow 1989), variable combinations were limited to 2 variables. We included all possible 2-variable combinations (except those in which the variables were correlated to each other by $r>0.70)$ in the multiple regression analysis, with either juveniles per female or the proportion of females with confirmed chicks as the dependent variable. Our suite of candidate models included 39 models for use in analysis of juveniles per female and 32 models for the analysis of proportion of females with confirmed chicks. Mean site-year data ( $n=8$ site-years) were used for all productivity analyses. We used Akaike's Information Criterion with small-sample bias adjustment $\left(\mathrm{AIC}_{c}\right)$ to select the most parsimonious model $(\mathrm{s})$ and Akaike weights $\left(w_{i}\right)$ to determine relative importance of habitat components (Burnham and Anderson 2002). Cumulative variable weights were estimated from the entire set of models. Productivity analyses were conducted using mean site-year data obtained from random plots (versus use plots). The weather variables and the juveniles-per-female values used in our analyses were site-level data, and we believed that data collected from random plots were more representative of annual site conditions.

We used ArcView GIS v3.2 (ESRI, Redlands, CA) to perform spatial analyses and Minitab Release 13 (Minitab, Inc. 1994) and SAS v8.2 (SAS Institute, Inc. 1990) to perform statistical analyses.

\section{Results}

Data used in analyses (i.e., site-years with more than 5 use plots) included data from Pinedale 1999 (9 use plots [i.e., locations for 9 different females with broods], 9 random plots),
2000 (8 use, 8 random), 2002 (16 use, 22 random), and 2003 (15 use, 24 random); Lander 2001 (7 use, 29 random), 2002 (9 use, 19 random), and 2003 (10 use, 39 random); and Kemmerer 2002 (8 use, 30 random). Productivity analyses were conducted using mean data from these years ( $n=8$ site-years). Hymenoptera were the most common arthropods sampled, making up nearly $60 \%$ of total arthropod abundance in both use and random habitats. Coleopterans were also fairly common, comprising just over $20 \%$ of total arthropod abundance. Most hymenopterans (73\%) and coleopterans $(62 \%)$ collected were adults in the medium length category. The majority of shrub cover was composed of sagebrush; mean sagebrush canopy cover from use and random locations combined was $20.0 \% \pm 0.7 \%\left(s_{\bar{x}}\right)$. Mean live sagebrush density was $1.7 \pm 0.1$ plants $\cdot \mathrm{m}^{-2}$; mean sagebrush height was 27.2 $\pm 0.6 \mathrm{~cm}$. Total herbaceous cover averaged $26.2 \% \pm 1.1 \%$; total forb cover and total grass cover averaged $4.9 \% \pm 0.4 \%$ and $9.0 \% \pm 03 \%$, respectively. Mean grass + residual grass height was $10.7 \pm 0.2 \mathrm{~cm}$.

\section{Habitat Use}

Fourteen of our 62 models had $\mathrm{AIC}_{c}$ values within 2 units of the minimum $\mathrm{AIC}_{c}$ value (Table 1), suggesting substantial support (Burnham and Anderson 2002). Thirteen of the 14 models statistically fit the data (HosmerLemeshow goodness-of-fit test statistics). In accordance with AIC principles (Burnham and Anderson 2002), all models were retained in the analysis (post hoc examination of the data after removing models that did not statistically fit the data [Hosmer and Lemeshow 1989] indicated that conclusions did not differ from the original analysis: cumulative Akaike weights indicating relative variable importance were virtually unaffected). Based on $\mathrm{AIC}_{c}$ weights, the top model was only marginally better in predicting habitat use than were the other 13 candidate models (i.e., evidence ratios were $\leq 2.7$; Burnham and Anderson 2002). However, although none of the models was clearly the best, the cumulative Akaike weight was fairly substantial for the sagebrush cover variable (0.71), indicating that it may be a good predictor of habitat use. Examination of directional trends of the regression data suggested that, compared to random areas, broods used areas with higher sagebrush canopy cover, 
TABLE 1. Candidate models explaining early brood-rearing habitat use of Greater Sage-Grouse in Pinedale (1999-2000, 2002-2003), Lander (2001-2003), and Kemmerer (2002), Wyoming. We based models $(n=62)$ on logistic regression analyses in which habitat type (use site $[n=82]$ or random site $[n=180]$ ) was the dependent variable. Models are ranked according to $\mathrm{AIC}_{c}$ methods (Burnham and Anderson 2002), and only models with $\Delta \mathrm{AIC}_{c} \leq 2$ are presented. Variables are live sagebrush cover (sage), live sagebrush density (liv_den), mean grass height (grass hgt), total grass cover (grass cover), total forb cover (forb), total herbaceous cover (herb), total invertebrate abundance (invert), total Hymenoptera abundance (Hymenopt), medium-length $(\geq 3 \mathrm{~cm}$ and $\leq 11 \mathrm{~cm}$ ) Hymenoptera abundance (medium Hymenopt), and medium-length $(\geq 3 \mathrm{~cm}$ and $\leq 11 \mathrm{~cm}$ ) Coleoptera abundance (medium Coleopt).

\begin{tabular}{|c|c|c|c|c|c|c|}
\hline Model & $\mathrm{K}^{*}$ & $\Delta \mathrm{AIC}_{c}^{\dagger}$ & $w_{i}^{\ddagger}$ & $\log _{e} L \S$ & $\begin{array}{c}\text { Goodness-of-fit }{ }^{\|} \\
\left(\chi^{2}, \mathrm{df}, P\right)\end{array}$ & $\begin{array}{l}\text { Direction } \\
\text { of trend }\end{array}$ \\
\hline Sage, invert & 3 & 0.00 & 0.07 & -159.45 & $7.46,8,0.49$ &,+- \\
\hline Sage, Hymenopt & 3 & 0.49 & 0.06 & -159.69 & $13.01,8,0.11$ &,+- \\
\hline Grass hgt, sage & 3 & 0.55 & 0.05 & -159.72 & $7.02,8,0.53$ &,++ \\
\hline Grass hgt, sage, invert & 4 & 0.87 & 0.05 & -159.85 & $7.42,8,0.49$ &,,++- \\
\hline Grass cover, sage & 3 & 1.12 & 0.04 & -160.01 & $8.54,8,0.38$ &,++ \\
\hline Grass hgt, sage, Hymenopt & 4 & 1.18 & 0.04 & -159.01 & $8.75,8,0.36$ &,,++- \\
\hline Grass cover, sage, invert & 4 & 1.34 & 0.04 & -159.09 & $5.84,8,0.67$ &,,++- \\
\hline Sage, medium Hymenopt & 3 & 1.53 & 0.03 & -160.21 & $9.36,8,0.31$ &,+- \\
\hline Sage, herb & 3 & 1.56 & 0.03 & -160.23 & $11.22,8,0.19$ &,++ \\
\hline Herb, sage, invert & 3 & 1.57 & 0.03 & -160.69 & $4.89,8,0.77$ &,,++- \\
\hline Sage, grass cover, Hymenopt & 3 & 1.67 & 0.03 & -159.20 & $7.67,8,0.47$ &,,++- \\
\hline Liv_den, grass hgt & 3 & 1.72 & 0.03 & -159.25 & $16.94,8,0.03$ &,++ \\
\hline Sage, medium Coleopt & 3 & 1.78 & 0.03 & -160.30 & $12.48,8,0.13$ &,+- \\
\hline Forb, sage & 4 & 1.93 & 0.03 & -160.34 & $13.28,8,0.10$ &,++ \\
\hline
\end{tabular}

*Number of variables in model + intercept

†Difference in values of Akaike's Information Criterion (with small-sample bias adjustment)

Percent of total weight (from all 62 models) that can be attributed to specified model

$\S$ Log-likelihood

"Hosmer-Lemeshow (1989) goodness-of-fit test

\#Direction of trend. The plus symbol (+) indicates that females with broods were using habitat with greater amounts of the variable; the minus symbol (-) indicates that broods used habitats with lesser amounts.

sagebrush density, total grass cover, and mean grass height, and lower invertebrate abundance (Table 1). Forb abundance was slightly positive, but appeared in only 1 of the top 14 models.

\section{Productivity}

Two models in the analysis of juveniles per female fell within 2 units of the minimum $\mathrm{AIC}_{c}$ value (Burnham and Anderson 2002). The top model had an $\mathrm{AIC}_{c}$ weight of 0.46 and contained the terms medium-length Hymenoptera abundance and total grass cover. The 2nd-ranked model included the variables medium-length Hymenoptera abundance and medium-length Coleoptera abundance $\left(\mathrm{AIC}_{c}\right.$ weight 0.17 ). The number of juveniles per female was positively associated with each of the independent variables in these top models. Based on cumulative $\mathrm{AIC}_{c}$ weights, the most important parameters influencing number of juveniles per female appeared to be medium-length Hymenoptera abundance and total grass cover (Table 2).

The analysis of the proportion of females with confirmed chicks 14 days post-hatch yielded only 1 highly plausible model, which contained the variables total herbaceous cover and medium-length Coleoptera abundance. The $\mathrm{AIC}_{c}$ weight associated with this model was 0.98 and the evidence ratio was 57.3 , suggesting that this model was likely the best model (Burnham and Anderson 2002). The proportion of females with confirmed chicks was positively associated with both total herbaceous cover and medium-length Coleoptera abundance. Total herbaceous cover and mediumlength Coleoptera abundance were also the most important individual parameters according to cumulative $\mathrm{AIC}_{c}$ weights (Table 2).

\section{Discussion}

Greater Sage-Grouse broods in Wyoming used habitats with greater sagebrush and grass cover but fewer insects compared to random sites. The abundance of forbs did not appear to play a large role in early brood habitat use. Though numerous researchers have examined habitat use by broods, results are somewhat inconsistent. Similar to our results, Greater Sage-Grouse in Colorado used areas with 
TABLE 2. Total and standardized cumulative $\mathrm{AIC}_{c}$ weights of variables used to predict juveniles per female (in fall wing barrel collections) and the proportion of females with confirmed chicks (14 days post-hatch) of Greater SageGrouse in Pinedale (1999-2000, 2002-2003), Lander (2001-2003), and Kemmerer (2002), Wyoming. Weights were standardized by the number of times a model (in the entire set of models) included the variable. Variables included were medium-length $(\geq 3 \mathrm{~cm}$ and $\leq 11 \mathrm{~cm}$ ) Hymenoptera abundance (medium Hymenopt), medium-length $(\geq 3 \mathrm{~cm}$ and $\leq 11$ $\mathrm{cm}$ ) Coleoptera abundance (medium Coleopt), total Hymenoptera abundance (Hymenopt), total invertebrate abundance (invert), total herbaceous cover (herb), total forb cover (forb), total grass cover (grass cover), mean new and residual grass height (grass hgt), percent of average April + May temperature / percent of average April + May precipitation (AprMay_TempPre), percent of average June temperature / percent of average June precipitation (Jun_TempPre), and percent of average July + August temperature / percent of average July + August precipitation (JulAug_TempPre).

\begin{tabular}{|c|c|c|c|c|}
\hline \multirow[b]{2}{*}{ Variable } & \multicolumn{2}{|c|}{ Chicks per female } & \multicolumn{2}{|c|}{ Early brood survival } \\
\hline & Cum. $w_{i}{ }^{*}$ & Std. cum. $w_{i}^{\dagger}$ & Cum. $w_{i}$ & Std. cum. $w_{i}$ \\
\hline Medium Hymenopt & 0.66 & 0.11 & 0.00 & 0.00 \\
\hline Medium Coleopt & 0.28 & 0.04 & 0.98 & 0.16 \\
\hline Hymenopt & 0.10 & 0.02 & 0.00 & 0.00 \\
\hline Invert & 0.14 & 0.03 & 0.00 & 0.00 \\
\hline Herb & 0.02 & 0.00 & 0.99 & 0.12 \\
\hline Forb & 0.08 & 0.02 & 0.00 & 0.00 \\
\hline Grass cover & 0.58 & 0.06 & 0.00 & 0.00 \\
\hline Grass hgt & 0.02 & 0.00 & 0.00 & 0.00 \\
\hline AprMay_TempPre & 0.02 & 0.00 & 0.02 & 0.00 \\
\hline Jun_TempPre & 0.07 & 0.01 & 0.00 & 0.00 \\
\hline JulĀug_TempPre & 0.03 & 0.00 & $\mathrm{NA}$ & NA \\
\hline
\end{tabular}

*Cumulative Akaike weight

†Standardized cumulative Akaike weight

greater sagebrush canopy cover than random sites (Dunn and Braun 1986); however, that study included not only females with broods, but juveniles and females that nested unsuccessfully. Schoenberg (1982) found no significant difference in sagebrush cover between brood use sites and random sites, whereas Klebenow (1969), Klott and Lindzey (1990), and Holloran (1999) documented brood use of sites with lower sagebrush or shrub cover than random sites. Greater Sage-Grouse broods in Idaho used areas with greater abundance of hymenopterans than nonbrood locations (Fischer et al. 1996). Numerous studies of other galliform species have found similar results: Common Capercaillie (Tetrao urogallus), Black Grouse (Tetrao tetrix), Lesser Prairie-Chicken (Tympanuchus pallidicinctus), and Ruffed Grouse broods have been documented selecting areas with greater invertebrate abundances than available areas (Storch 1994, Baines et al. 1996, Jamison et al. 2002, Haulton et al. 2003). In contrast, our broods were found in areas with lower amounts of invertebrates than were generally available.

One potential reason for discrepancies between our results and those from other studies is that investigator presence had an effect on habitat use. Although we made every attempt to avoid disturbing birds during radio- tracking, it is possible that the birds changed their focus from foraging to escape once they heard or saw investigators. This scenario could have biased our results toward security cover (i.e., increased sagebrush cover) and away from foraging habitat (i.e., increased arthropods and forbs). Greater Sage-Grouse are often found near habitat edges (Dunn and Braun 1986), so even small-scale movements of 5-10 m may have been enough to shift birds between different habitat types. Although we do not believe that we influenced brood habitat use, if broods did move during the tracking process, it would suggest that they were feeding in areas closely associated with suitable security cover.

We believe a more likely explanation is based on temporal differences between studies. Our study examined brood habitat use early in the brood-rearing period (before chicks were 2 weeks old). Holloran (1999) collected data on chicks between 2 and 4 weeks of age; Klebenow (1969) examined habitat use by broods up to 7 weeks of age; and Klott and Lindzey (1990) obtained brood locations throughout the summer. Grouse chicks experience heavy losses within the 1st few weeks of life. Survival of Greater Sage-Grouse chicks to 21 days old in Idaho ranged from $21 \%$ to $50 \%$ (Burkepile et al. 2002), and between $14 \%$ and $33 \%$ of chicks survived to 50 days in Washington and 
Canada (Schroeder 1997, Aldridge and Brigham 2001). Crawford et al. (2004) averaged the results of 3 studies to estimate a $10 \%$ survival rate from hatch to the 1st potential breeding season. These studies did not examine how much mortality occurred during the first 14 days; however, Holloran (1999) documented the majority of chick loss during the first 2-3 weeks. Patterson (1952) suggested that, although a myriad of factors may be involved, losses to predation potentially account for the greatest amount of juvenile mortality in Greater Sage-Grouse. In addition, several authors suggest that predation may be 1 factor limiting annual tetraonid productivity (Batterson and Morse 1948, Marcström et al. 1988, Baines 1991).

Greater Sage-Grouse broods in Wyoming appeared to be selecting habitats with increased security cover during the first 2 weeks posthatch. Chicks are generally not capable of flight before 10-14 days of age (Girard 1937, Wallestad 1975); thus, the presence of dense protective cover may be even more important for females with younger broods than for older broods that have alternate means of escape. The need for foraging areas in close proximity to protective cover has been well documented (Klebenow 1969, Wallestad 1971, Klott and Lindzey 1990, Sveum et al. 1998, Holloran 1999). Insect abundances were negatively correlated with sagebrush cover $(r=-0.15$ for total arthropods; $r=-0.12$ for optimal-length Hymenoptera; and $r=-0.11$ for total Hymenoptera); thus, lower levels of this component in brood use areas in Wyoming were likely an artifact of these correlations and not selection.

Forb cover did not appear to be a driving factor in early brood habitat use. Although many studies have documented brood use of sites with high forb abundance (Klebenow 1969, Klott and Lindzey 1990, Sveum et al. 1998, Holloran 1999), these studies examined habitat use later in the brood-rearing period. Because we examined early brood habitat use by 14 days post-hatch, forbs may not yet have been the main component of the diet. Patterson (1952) suggests that vegetation begins to gain importance in chick diets after the 1st few weeks of life. Klebenow and Gray (1968), Peterson (1969), and Huwer (2004) found that invertebrates dominated the diets of Greater Sage-Grouse chicks during the 1st week, before forbs began to gain importance as a food source.
The ratio of juveniles to adult females in the fall harvest appeared to be most strongly influenced by invertebrate abundance and grass cover. Our top 2 models both included mediumlength Hymenoptera abundance. Hymenopterans, primarily ants (Formicidae) in our study, are an important food item for young chicks; ants were found in $75 \%$ of the crops of birds 1-4 weeks old in Montana (Peterson 1970) and in up to $100 \%$ of the crops of juvenile Greater Sage-Grouse collected in Idaho (Klebenow and Gray 1968). Johnson and Boyce (1990) found that insects were crucial for survival of young sage grouse chicks, and studies of several other galliform species have found that invertebrate abundance was positively associated with productivity (Green 1984, Hill 1985, Park et al. 2001). Total grass cover was the top vegetation variable; nearly $60 \%$ of the $\mathrm{AIC}_{c}$ weight was attributed to models that included this variable. Grass cover likely served a protective function by screening foraging broods from potential predators.

The factors associated with the proportion of females with confirmed chicks appeared to be well defined. AIC analysis yielded only 1 highly plausible model containing the variables medium-length Coleoptera abundance and total herbaceous cover. Like hymenopterans, coleopterans are often a principal component in juvenile Greater Sage-Grouse diets (Klebenow and Gray 1968, Peterson 1970). Total herbaceous cover was composed of both grasses and forbs; therefore, it may have served the dual function of providing both protection and food sources. Total forb cover was positively correlated with both medium-length Hymenoptera $(r$ $=0.68)$ and medium-length Coleoptera $(r=$ 0.81 ) abundances. Although forb cover did appear in a 2nd-tier model (i.e., $\Delta \mathrm{AIC}_{c}$ between 2 and 4) in the analysis of juveniles per female, it was not strongly related to the proportion of females with confirmed chicks. Again, because we examined this measure of productivity by 14 days post-hatch, forbs may not yet have been the major component of the diet.

We found virtually no relationship between weather and productivity. It is possible that short-term, extreme weather conditions (e.g., heavy rainfall, severe cold spells) influenced productivity, but these occurrences were not detectable using annual weather data. However, the trends we did observe were consistent; all weather variables were positively associated 
with our 2 measures of productivity. Warm and dry conditions appeared to be more favorable for productivity than cold and wet conditions.

Our study suggests that abundant mediumlength insects within heavy sagebrush cover will be most beneficial to juvenile Greater SageGrouse. During the early brood-rearing period, broods used sites within or near dense (average $20 \%$ canopy cover) sagebrush cover, and increased productivity was positively associated with abundance of insects and herbaceous cover. Although managing directly for invertebrates is likely not feasible, it may be possible to indirectly manage for higher insect abundance through manipulation of vegetation. Invertebrate biomass is positively correlated to forb abundance (Southwood and Cross 1969, Blenden et al. 1986, Hull et al. 1996, Jamison et al. 2002); thus, enhancement of the forb component could serve a dual function by directly providing a food resource while ensuring the availability of insects. However, development and maintenance of a productive forb layer should not come at the expense of sagebrush cover. The overriding factor affecting habitat use by Greater Sage-Grouse broods appeared to be the presence of protective sagebrush cover; therefore, cover should be maintained while the understory forb layer is increased. Managing for a productive understory within dense sagebrush stands should help ensure high-quality early brood-rearing habitat and enhance the potential for increased Greater Sage-Grouse productivity.

\section{ACKNOWLEDGMENTS}

Funding was provided by the Wyoming Game and Fish Department, Bureau of Land Management, Department of Energy, 3-Shot Sage-grouse Foundation, Yellowstone-to-Yukon Initiative, EnCana Oil and Gas, and the Animal Damage Management Board. We thank D.R. Edmunds, R.A. Holloran, B.K. Holtby, M.A. Kaemingk, A.G. Lyon, Mr. and Mrs. T.W. Malmberg, C.M. Sazama, C.G. Taber, Mr. and Mrs. N.A. Tratnik, and G.L. Wilson for assistance with field research. France Flying Service (Rawlins, WY) and Mountain Air Research (Driggs, ID) provided logistical support. We thank A.D. Apa, A.J. Carlson, J.W. Connelly, W.A. Hubert, D.D. Paulson, S.E. Richman, and an anonymous reviewer for valuable comments on earlier versions of this manuscript.

\section{Literature Cited}

Aldridge, C.L., And R.M. Brigham. 2001. Nesting and reproductive activities of Greater Sage-Grouse in a declining northern fringe population. Condor 103: $537-543$.

Aulie, A. 1976. The pectoral muscles and the development of thermoregulation in chicks of Willow Ptarmigan (Lagopus lagopus). Comparative Biochemistry and Physiology 53A:343-346.

Autenrieth, R., M. Molini, and C. Braun. 1982. Sage grouse management practices. Western States Sage Grouse Committee, Technical Bulletin 1. Twin Falls, ID. 42 pp.

BaInes, D. 1991. Factors contributing to local and regional variation in Black Grouse breeding success in northern Britain. Ornis Scandinavica 22:264-269.

Baines, D., I.A. Wilson, And G. BeEley. 1996. Timing of breeding in Black Grouse Tetrao tetrix and Capercaillie Tetrao urogallus and distribution of insect food for the chicks. Ibis 138:181-187.

Batterson, W.M., And W.B. Morse. 1948. Oregon sage grouse. Oregon Fauna Serv. 1. Oregon Game Commission, Portland. 29 pp.

Bergerud, A.T. 1988. Population ecology of North American grouse. Pages 578-685 in A.T. Bergerud and M.W. Gratson, editors, Adaptive strategies and population ecology of northern grouse. University of Minnesota Press, Minneapolis.

Blank, T.H., T.R.E. Southwood, and D.J. Cross. 1967. The ecology of the partridge. Outline of population processes with particular reference to chick mortality and nest density. Journal of Animal Ecology 36: 549-556.

Blenden, M.D., M.J. Armbruster, T.S. Baskett, and A.H. Farmer. 1986 Evaluation of model assumptions: the relationship between plant biomass and arthropod abundance. Pages 11-14 in J. Verner, M.L. Morrison, and C.J. Ralph, editors, Modeling habitat relationships of terrestrial vertebrates. University of Wisconsin Press, Madison.

Braun, C.E. 1998. Sage grouse declines in western North America: what are the problems? Pages 139-156 in Proceedings, Western Association of Fish and Wildlife Agencies, 1998 June 26-July 2; Jackson, WY.

Burkepile, N.A., J.W. Connelly, D.W. Stanley, and K.P. REESE. 2002. Attachment of radiotransmitters to oneday-old sage grouse chicks. Wildlife Society Bulletin 30:93-96.

Burnham, K.P., AND D.R. Anderson. 2002. Model selection and multimodel inference: a practical information-theoretic approach. 2nd edition. Springer-Verlag, New York. 488 pp.

Burrough, P.A., And R.A. McDonnell. 1998. Principles of geographical information systems. Oxford University Press, New York. 333 pp.

Canfield, R. 1941. Application of the line intercept method in sampling of range vegetation. Journal of Forestry 39:386-394.

Connelly, J.W., S.T. Knick, M.A. Schroeder, and S.J. STIVER. 2004. Conservation assessment of Greater Sage-Grouse and sagebrush habitats. Unpublished Report, Western Association of Fish and Wildlife Agencies, Cheyenne, WY. 601 pp.

Connelly, J.W., M.A. Schroeder, A.R. Sands, and C.E. Braun. 2000. Guidelines to manage sage grouse 
populations and their habitats. Wildlife Society Bulletin 28:967-985.

Crawford, J.A., R.A. Olson, N.E. West, J.C. Mosley, M.A. Schroeder, T.D. Whitson, R.F. Miller, et AL. 2004. Ecology and management of sage-grouse and sage-grouse habitat. Journal of Range Management 57:2-19.

Dalke, P.D., D.B. Pyrah, D.C. Stanton, J.E. Crawford, AND E.F. SChlatterer. 1963. Ecology, productivity, and management of sage grouse in Idaho. Journal of Wildlife Management 27:811-841.

Daubenmire, R.F. 1959. A canopy-coverage method of vegetational analysis. Northwest Science 33:43-64.

Drut, M.S., W.H. Pyle, and J.A. Crawford. 1994a. Technical note: diets and food selection of sage grouse chicks in Oregon. Journal of Range Management 47:90-93.

Drut, M.S., J.A. Crawford, and M.A. Gregg. 1994b. Brood habitat use by sage grouse in Oregon. Great Basin Naturalist 54:170-176.

Dunn, P.O., And C.E. Braun. 1986. Summer habitat use by adult female and juvenile sage grouse. Journal of Wildlife Management 50:228-235.

ErikstaD, K.E. 1985. Growth and survival of Willow Grouse chicks in relation to home range size, brood movements and habitat selection. Ornis Scandinavica 16:181-190.

ESRI, INC. 1998. Introduction to ArcView ${ }^{\circledR}$ GIS. Environmental Systems Research Institute, Inc., Redlands, CA. 604 pp.

Fischer, R.A., K.P. ReEse, AND J.W. Connelly. 1996. An investigation of fire effects within xeric sage grouse brood habitat. Journal of Range Management 49: 194-198.

Flanders-Wanner, B.L., G.C. White, and L.L. McDanIEL. 2004. Weather and prairie grouse: dealing with effects beyond our control. Wildlife Society Bulletin 32:22-34.

Giesen, K.M., T.J. Schoenberg, and C.E. Braun. 1982. Methods for trapping sage grouse in Colorado. Wildlife Society Bulletin 10:224-231.

GirarD, G.L. 1937. Life history, habits and food of the sage grouse, Centrocercus urophasianus Bonaparte. University of Wyoming Publications, Publication 3. University of Wyoming, Laramie. 56 pp.

1939. Notes on life history of the shoveler. Transactions of the North American Wildlife Conference 4:364-371.

Green, R.E. 1984 The feeding ecology and survival of partridge chicks (Alectoris rufa and Perdix perdix) on arable farmland in East Anglia. Journal of Applied Ecology 21:817-830.

Greenslade, P.J.M. 1964. Pitfall trapping as a method for studying populations of Carabidae (Coleoptera). Journal of Animal Ecology 33:301-310.

Haulton, G.S., D.F. StaufFer, R.L. KirKPatrick, and G.W. Norman. 2003. Ruffed Grouse (Bonasa umbellus) brood microhabitat selection in the southern Appalachians. American Midland Naturalist 150:95-103.

Hill, D.A. 1985. The feeding ecology and survival of pheasant chicks on arable farmland. Journal of Applied Ecology 22:645-654.

Holloran, M.J. 1999. Sage grouse (Centrocercus urophasianus) seasonal habitat use near Casper, Wyoming. Master's thesis, University of Wyoming, Laramie.

Hosmer, D.W., AND S. Lemeshow. 1989. Applied logistic regression. John Wiley \& Sons, New York. 307 pp.
Hull, S.D., R.J. Robel, and K.E. Kemp. 1996. Summer avian abundance, invertebrate biomass, and forbs in Kansas CRP. Prairie Naturalist 28:1-12.

Huwer, S.L. 2004. Evaluating Greater Sage-Grouse brood habitat using human-imprinted chicks. Master's thesis, Colorado State University, Fort Collins.

Jamison, B.E., R.J. Robel, J.S. Pontius, and R.D. AppleGATE. 2002. Invertebrate biomass: associations with Lesser Prairie-Chicken habitat use and sand sagebrush density in southwestern Kansas. Wildlife Society Bulletin 30:517-526.

Johnson, G.D., AND M.S. BoyCE. 1990. Feeding trials with insects in the diet of sage grouse chicks. Journal of Wildlife Management 54:89-91.

KLeBenOW, D.A. 1969. Sage grouse nesting and brood habitat in Idaho. Journal of Wildlife Management 33:649-661.

Klebenow, D.A., And G.M. Gray. 1968. Food habits of juvenile sage grouse. Journal of Range Management 21:80-83.

KLotT, J.H., AND F.G. Lindzey. 1990. Brood habitats of sympatric sage grouse and Columbian Sharp-tailed Grouse in Wyoming. Journal of Wildlife Management 54:84-88.

KuIPERS, J.L. 2004. Grazing system and linear corridor influences on Greater Sage-Grouse (Centrocercus urophasianus) habitat selection and productivity. Master's thesis, University of Wyoming, Laramie.

LYon, A.G. 2000. The potential effects of natural gas development on sage grouse near Pinedale, Wyoming. Master's thesis, University of Wyoming, Laramie.

Marcström, V., R.E. Kenward, and E. Engren. 1988. The impact of predation on boreal tetraonids during vole cycles: an experimental study. Journal of Animal Ecology 57:859-872.

Martin, N.S. 1970. Sagebrush control related to habitat and sage grouse occurrence. Journal of Wildlife Management 34:313-320.

Minitab, InC. 1994. Minitab ${ }^{\circledR}$ user's guide, release 10 for Windows. State College, PA. 268 pp.

Myhre, K., M. CabanaC, And G. Myhre. 1975. Thermoregulatory behavior and body temperature in chicks of Willow Grouse (Lagopus lagopus lagopus). Poultry Science 54:1174-1179.

Neave, D.J., AND B.S. Wright. 1969. The effects of weather and DDT spraying on a Ruffed Grouse population. Journal of Wildlife Management 33:1015-1020.

Park, K.J., P.A. Robertson, S.T. Campbell, R. Foster, Z.M. Russell, D. Newborn, and P.J. Hudson. 2001. The role of invertebrates in the diet, growth and survival of Red Grouse (Lagopus lagopus scoticus) chicks. Journal of Zoology, London 254:137-145.

Patterson, R.L. 1952. The sage grouse in Wyoming. Wyoming Game and Fish Commission. Sage Books, Inc., Denver, CO. 341 pp.

Peterson, J.G. 1970. The food habitats and summer distribution of juvenile sage grouse in central Montana. Journal of Wildlife Management 34:147-155.

Pyle, W.H., and J.A. Crawford. 1996. Availability of foods of sage grouse chicks following prescribed fire in sagebrush-bitterbrush. Journal of Range Management 49:320-324.

RITCEY, R.W., AND R.Y. EDWARDS. 1963. Grouse abundance and June temperatures in Wells Gray Park, British Columbia. Journal of Wildlife Management 27:604606. 
SAS InSTITUTE, INC. 1990. SAS/STAT ${ }^{\circledR}$ user's guide, version 6. 4th edition. Volume 2. SAS Institute, Cary, NC. $846 \mathrm{pp}$.

SchoenberG, T.J. 1982. Sage grouse movements and habitat selection in North Park, Colorado. Master's thesis, Colorado State University, Fort Collins.

SCHRoEdER, M.A. 1997. Unusually high reproductive effort by sage grouse in a fragmented habitat in northcentral Washington. Condor 99:933-941.

Schroder, M.A., J.R. Young, And C.E. Braun. 1999. Sage grouse (Centrocercus urophasianus). Pages 1-28 in A. Poole and F. Gill, editors, The Birds of North America, no. 425. The Birds of North America, Inc., Philadelphia, PA.

SLATER, S.J. 2003. Sage grouse (Centrocercus urophasianus) use of different-aged burns and the effects of coyote control in southwestern Wyoming. Master's thesis, University of Wyoming, Laramie.

SMYTH, K.E., AND D.A. BoAG. 1984. Production in Spruce Grouse and its relationship to environmental factors and population parameters. Canadian Journal of Zoology 62:2250-2257.

Sokal, R.R., and FJ. Rohlf. 1995. Biometry. 3rd edition. W.H. Freeman, New York. 887 pp.

Southwood, T.R.E., AND D.J. CRoss. 1969. The ecology of the partridge. III. Breeding success and the abundance of insects in natural habitats. Journal of Animal Ecology 38:497-509.
STORCH, I. 1994. Habitat and survival of Capercaillie Tetrao urogallus nests and broods in the Bavarian Alps. Biological Conservation 70:237-243.

Stubbendieck, J., S.L. Hatch, and L.M. Landholt. 2003. North American wildland plants: a field guide. 6th edition. University of Nebraska Press, Lincoln. 501 pp.

Sveum, C.M., J.A. Crawford, AND W.D. Edge. 1998. Use and selection of brood-rearing habitat by sage grouse in south central Washington. Great Basin Naturalist 58:344-351.

Wakkinen, W.L., K.P. Reese, J.W. Connelly, and R.A. FISCHER. 1992. An improved spotlighting technique for capturing sage grouse. Wildlife Society Bulletin 20:425-426.

WALLSTAD, R.O. 1971. Summer movements and habitat use by sage grouse broods in central Montana. Journal of Wildlife Management 35:129-136.

. 1975. Life history and habitat requirements of the sage grouse in central Montana. Division of Wildlife, Montana Department of Game and Fish. 65 pp.

Whitmore, R.W., K.P. Pruess, and R.E. Gold. 1986. Insect food selection by 2 -week-old Ring-necked Pheasant chicks. Journal of Wildlife Management 50:223-228.

Received 3 May 2005 Accepted 17 October 2005 